\title{
FOOD-BORNE BACTERIA ASSOCIATED WITH CONTAMINATED FISHES: A BRIEF REVIEW
}

\author{
Nazia Khan* \\ Kaleem Ullah \\ Department of Microbiology, University of Balochistan, Quetta 87300, Balochistan, Pak- \\ istan *Corresponding author \\ Department of Microbiology, University of Balochistan, Quetta 87300, Balochistan, Pakistan \\ Telephone: 03337784006; Email: naziakhanmarri850@ gmail.com
}

\begin{abstract}
Fish is considered a good source of protein and is consumed in many countries. Fish is a source of high protein giving approximately $16 \%$ of animal protein taken up by world's population. Fish consist of high nutritional values like essential fatty acids, low saturated fat and omega-3 fatty acid which cannot be produced by human body. Majority of fish species resides in water, some burry themselves in mud and carry bacteria from into gut and skin. Microbiological contamination of fish is dependent on condition of water source. The normal flora of fish is constantly affected by bacterial contamination of water, contamination from wastewater and from sediments. The ingestion of contaminated fish and its products leads to foodborne infections, hence the occurrence of fish pathogens increase alarm about the product safety issue. These foodborne infections may arise from other sources like improper handling, storage, packaging and consumption of raw fish. Many people acquire infection by contact during handling of water, and by contact with other elements of fish living environment.
\end{abstract}

Keywords: Fishes, Microorganism, Environment, Diseases, Human

\section{Introduction}

Majority of the bacteria linked with fish illnesses are naturally saprophytic organisms, extensively scattered in the marine environment. Comparatively limited species are classified as true obligate pathogens. Both assemblies of organisms may be present on the exterior surface of body or in the tissues of deceptively healthy fish. Food tolerated illnesses are the common complications encountered even in these up-to-date days, which is said to be the period of scientific expansion (Bishor and Elezebeth, 1989).

\section{Effect of antibiotic on fishes}

The quantity of drugs (antibiotics) utilized for the treatment purposes of fish derived illnesses has been increased these days due to increase in production of fish. Numerous studies have been documented the defective usage of antibiotics in marine culture which has led to increase in resistance of antibiotic in many fish pathogens. 
Moreover, occurrence of antibiotic residues in fish foodstuffs and sea food has augmented as well. Additionally, the appearance of resistance of antibiotic might be transmitting from marine environment to animals and humans. For some aspect of primary health care according to the report of WHO (World Health Organization) about eighty percent of the population of world currently uses herbal medicines (Bishor and Elezebeth, 1989).

\section{Fish and its microflora}

Fish microflora, fish from natural surroundings are acknowledged to harbor numerous classes of bacteria (Pillay, 1990). Colonization of bacteria can be detected on gills and skin of fish as a consequence of continuous or long experience to water contamination, though the digestive tract might be affected by water or polluted feed. When immunological resistance is cooperated contamination of fish muscles is also probable (Guzman, 2004). A few microorganism numbers can be found on skin of fish mostly. For example, studies in the United Kingdom revealed that the total bacteria count on salmon skin wide-ranging from $10^{2}-10^{3} \mathrm{CFU} / \mathrm{cm}^{2}$. In the meantime, a related study was done in Turkey reported that a higher quantity of $10^{1}$ to $10^{7} \mathrm{CFU} / \mathrm{cm}^{2}$ on skin of Salmon (Diler et al., 2000), also aerobic microbes were noticed more frequently than anerobic ones (Nedoluha and Westhoff, 1997). It is presumed that on skin of fish, bacteria are present which are similar to those which are present in the $\mathrm{H}_{2} \mathrm{O}$ contamination, containing species and genera as Aeromonas species Proteus species., Moraxella spp., Flexibacter spp., Providencia spp., Escherichia coli., Enterobacter aerogenes., and Vibrio fluvialis (Christensen, 1997; Allen et al, 1983; Youssef et al., 1992).

\section{Bacterial habits in fishes}

Healthy fishes interior organs and muscles are generally free of germs. Though, few studies defined the occurrence of bacteria in the liver (Pseudomonas species. Vibrio species including V. harveyi, V. pelagius) and kidneys of turbot (Scophthalmus maximus) (Evelyn and McDermott, 1967; Toranzo et al., 1993). The maximum bacterial number were detected in digestive tract and gills of fish and can reach one hundred six CFU/g and $10^{8}$ CFU/g, respectively (Trust and Sparrow, 1994). The maximum and the minimum conclusions for exact bacteria were associated to the temperature, water change and were detected throughout the summer and winter seasons. There are variations in the bacteria numbers besides the aerobic bacteria count fluctuated between $5.5 \times 10^{3}$ to $5.0 \times 10^{4} \mathrm{CFU} / \mathrm{g}$, and from $1.0 \times 10^{4}$ to $10 \times 10^{6} \mathrm{CFU} / \mathrm{g}$ in intestines and stomach of the fishes based on the fragment of digestive tract (Diler and Diler, 1998). The amount of microorganisms in the digestive tract has been observed that it hinge on the sort of fish food and high number of bacteria was in debris consumers than that of filter feeding $\mathrm{H}_{2} \mathrm{O}$ (Balasubramanian et al., 1992).

\section{Vibrio Species effects on fishes}

In fish environment and fish, Vibrio specie are extensively disseminated. Numerous Vibrio species may generate grave illness in cultured and wild fish both, and the fish virulent types including $V$. anguillarum (red pest in eels), V. ordalii (septicaemia in salmonids), V. viscous, V. vulnificus (warm water vibriosis) (Gauthier, 2015). Among Vibrio species, V. cholerae and V. vulnificus have concerned in human vibriosis linked with feeding of shellfish and fish. V. vulnificus and Vibrio cholerae are autochthonal to numerous aquatic environments, but despite exhaustive hard work, its transmission and ecology by contaminated fish remains unclear. About the role 
of fish inadequate studies present in $V$. cholerae causes illness; though, adulteration of fish as high as $50 \%$ was testified (Senderovich et al., 2010). More often V. vulnificus is linked with human vibriosis and illness frequently arises because feeding of inadequately heat-preserved fish foodstuffs or fish (Callol et al., 2015). The 3 biotypes of $V$. vulnificus have been defined of which biotype one has been isolated more frequently from humans and water. In the meantime, biotype two was highly isolated from humans and fish (Gauthier, 2015). Feeding of food associated to sea products in spite of the observed connection of human and fish isolated bacteria tested with methods like MLST (Multi locus sequence typing) and VNTR (variable number of tandem repeat). While $V$. vulnificus biotype three has not been linked yet (Broza et al., 2009).

Presence of Vibrio is plentiful in aqua environment, and on gill, intestinal tract and skin of shellfish and fish. V. parahaemolyticus and $V$. vulnificus higher statistics was defined in intestine of fish in contrast to sediment and water samples. Temperature and salinity may affect the occurrence of Vibrio species in aquatic environment and fish. The presence of bacteria is more observed in warm and lower salinity water (Givens et al., 2014). The occurrence of V. vulnificus was $37 \%$ after testing of samples of 242 fish classes in a study carried out in Mexico. Furthermore, the augmentation in occurrence of $V$. vulnificus up to $69 \%$ was detected in summer period (Tao et al., 2012). V. parahaemolyticus is often linked with the molluscan; however, augmented occurrence of such type of bacteria is also detected in fish, and the antigen was observed in more than $50 \%$ of verified fish samples in different countries including Malaysia, Indonesia, and Vietnam (Nakaguchi, 2013). The presence of Vibrio is seen higher in aquatic fish. For example, $40 \%$ of Tilapia and $24 \%$ of catfish were polluted with $V$. parahaemolyticus in a study was done in Malaysia (Noorlis et al., 2011).

\section{Listeria monocytogenes effects on fishes}

Listeria monocytogenes are the contributing mediator of listeriosis. In spite of its little prevalence, the death percentage in those who are vulnerable, such as immunocompromised persons, may reach 20-40\% (Lianou and Sofos, 2007). Listeria monocytogenes are pervasive in the atmosphere and been secluded from the animal stools, silage, soil, from marine and fresh waters, and sediments. Listeria classes can be institute in diverse kind of source of waters, and these microorganisms were frequently isolated from polluted water with high ratio of organic materials, including coastal areas and rivers (Embarek, 1994). The incidence of Listeria monocytogenes about $6.6 \%$ in fishes from fresh waters by contamination of the lake environment due the sewerage systems of cities (Ertas and Seker, 2005). It is important to mention that the occurrence of Listeria monocytogenes associates with variety of activities which are carried by the human. In watercourses of fresh waters, pathogens were not detected but was occur in fish farms of sea water (2\%) and fish farms of fresh waters (10\%) in slaughterhouses of fish about $16 \%$, as well as smokehouses of fish about $68 \%$ (Hansen et al., 2006).

Current study proposed the new species of Listeria including Listeria aquatica, Listeria riparia, Listeria grandensis, and Listeria floridensis (Den-Bakker et al., 2014) in samples from environments. In fish remnants occurrence of virulence bacterial species is uncertain, although their occurrence in environment of $\mathrm{H}_{2} \mathrm{O}$ may be helpful as a pointer of thinkable pollution with Listeria monocytogenes (Wagner and McLauchlin, 2008). In the environment such as water environment, perseverance of Listeria monocytogenes and other Listeria species relies 
the numerous aspects. Such as on of this factor, the potential of Listeria species to multiply and survive at high temperature. Listeria monocytogenes has largest existence rate in both sewerage and water at $4{ }^{\circ} \mathrm{C}$, where the majority of the microorganism's survival time is from approximately 120 to 140 days (Budzińska et al., 2012).

\section{Yersinia species effects on fishes}

Yersinia species are acknowledged to pathogens of human, and it is also a causative agent of disease in animals. Grounded on its biochemical properties, Yersinia enterocolitica is separated in to 6 biotypes, 5 are pathogenic and only 1 is nonpathogenic (Wauters et al., 1987). In the interim, all bacteria strains of Yersinia pseudotuberculosis known as pathogenic to humans and can be divided in to 4 biotypes (Tsubokura and Aleksić, 1995). Red mouth disease in fish is caused by Yersinia ruckeri and it is considered as fish pathogen (Ewing et al., 1978).

Classes of bacteria resultant from genus Yersinia, Y. enterocolitica and Yersinia pestis frequently mutually termed as Yersinia enterocolitica like species (Sulakvelidze, 2002). Yersinia genus members can cultivate under the anaerobic and aerobic culture circumstances with optimal development rate at $29^{\circ} \mathrm{C}$ and from 4 to $42^{\circ} \mathrm{C}$ is the satisfactory range (Bottone et al., 2005). The potential to multiply and survive at very minimal temperature of Yersinia enterocolitica is so special attention. From amalgamation of numerous factors adaptation of this microorganisms to cold is results that support to uphold the significant roles of cell after and throughout the cold shock. Process of cold version including their programming genes, upregulation of dedicated cold shock proteins, fatty acids structure and well-matched solutes that serve as osmotic balancers in cells (Bresolin et al., 2006).

Yersinia enterocolitica can survive in the streams of water at the temperature of $4{ }^{\circ} \mathrm{C}$ for up to 64 weeks and maximum up to the period of five years in sterile water it has been defined (Karapinar and Gonul, 1991).

\section{Clostridium botulinum effects on fishes}

Clostridium botulinum is extensive in environment and befalls naturally in aquatic and soil environment. Because to the making of botulinum neurotoxin, Clostridium botulinum is responsible for botulism. There are 8 kinds of botulinum neurotoxin are currently recognized (Smith and Sugiyama, 1998). The nature of Clostridium botulinum spores forming indorses existence of this bacterium in the atmosphere. In residues of water and fish, the occurrence of Clostridium botulinum can be prejudiced by numerous reasons, including feeding habits of species, geographical location and types of samples and the methods used for detection. Clostridium botulinum was found in numerous fish samples and residues of water (Johannsen, 1962; Bott et al., 1966; Fach et al., 2002; Leclair et al., 2012). In area of Baltic Sea, marine residues samples exposed a very great occurrence of Clostridium botulinum type $\mathrm{E}$ which is about $100 \%$. Therefore, sea nethermost residues can be measured as a foremost pool for Clostridium botulinum type E in the area of Baltic Sea. Mainly from Baltic herring, numerous species of fish are utilized for the marketable purpose studies. The presence of Clostridium botulinum type $\mathrm{E}$ in numerous nonfarmed species of fish of commercial purpose trapped from the Baltic Sea area. Non-farmed marine fishes sample examined, in which $23 \%$ of fish contained $C$. botulinum type E and among these maximum 
occurrence of $C$. botulinum type $\mathrm{E}$ was present about $40 \%$, the area of Baltic herring trials. The presence of Clostridium botulinum type $\mathrm{E}$ is recommended the greater in lowest nourishing fish as related to the pelagic fish (Huss and Pedersen, 1979). In the European river lamprey area minimal presence of Clostridium botulinum was originated. Moreover (Merivirta et al., 2006) described the consequences on occurrence of Clostridium botulinum in European river lamprey got from Finnish rivers. From twelve different rivers, rolling into Gulf of Bothnia lampreys were together. Sea upstream to the spawn lampreys are generally trapped throughout the period of relocation. Clostridium botulinum type E were recognized in 1 to $15 \%$ of the collected samples. Additionally, a study was carried out to examine the type of Clostridium botulinum distribution and occurrence in fish trapped from the farms and in Finnish trout farm residues.

Fish samples were designated for the study related to 4 species of fish including rainbow trout, Sea trout, Whitefish, and lake trout. For occurrence of Clostridium botulinum type E out of 125 residues samples, about 165 samples of fish intestine examined, 68 and $15 \%$, respectively, were positive. None of the type A, B, or F were identified in residues or samples of trout fish farms. The study outcomes suggested that the project of fish farms can effect highly in incidence of Clostridium botulinum in samples of fish farms. Clostridium botulinum level was detected which was meaningfully minor in fish intestine samples in self-cleaning freshwater ponds than in other traditional pond earth farms. Occurrence of Clostridium botulinum in fishes of fresh water and residues samples from the northern area of France has reported as $25 \%$ of the calculated residues samples, about $16.6 \%$ of fishes of seawater and about $4 \%$ of freshwater fishes (Fach et al., 2002). $70 \%$ type B of the Clostridium botulinum positive samples, were confirmed that occurred in maximum amount and the occurrence of type A was just 22.5 $\%$. Disease epidemics in fish eating birds have connected with digestion of fish polluted with the Clostridium botulinum. In 1996, Salton Sea avian botulism epidemic was reported associated to fish as the cause of Clostridium botulinum type C toxin (Rocke et al., 2004). Moreover, tilapia carry Clostridium botulinum within their digestive tract in Salton Sea and capable of making neurotoxin. In fish the existence of $C$. botulinum type $\mathrm{E}$ leads to a great hazard of fish product contamination. Numerous human botulism epidemics have been described globally by reason of feeding of fish yields. 91 case of botulism in Cairo, Egypt were triggered via feeding of uneviscerated, salted mullet fish described a type E botulism epidemic that elaborate 2 peoples in Finland, and was connected to vacuum-filled smoke whitefish. To abolish $C$. botulinum spores temperature throughout the hotsmoking process of fish typically is not adequate, thus the growth and neurotoxin production of $C$. botulinum type E to storage above $3{ }^{\circ} \mathrm{C}$ and vacuum-packaging of smoked whitefish may subsidize (Weber et al., 1993, Lindström et al., 2006).

\section{Fishes as pathogenic vector}

Fishes acting as vector of human enteropathogenic bacteria due to marvelous expansion in the field of aquaculture industry, augmented consideration has been given to the possibility. Moreover, different widespread studies have been done so far on wastewater fishes (Buras et al., 1987). From different types of species of fish, both from temperate and tropical waters wide variety of bacteria has been isolated. The types of bacteria supported in the gastrointestinal tracts of fish are connected to a certain degree to the level of water contamination 
by enteric bacteria there are supporting evidences about this. As per the previously done lessons by (Geldreich and Clarke, 1996), the bacteriological quality of the water reflect the microbiological flora of fish from where the fish coming. Most of these bacteria are taken in the digestive tract and they are of main consequence as foundation of work-related diseases in handlers of fish (Reichenbach, 1973). The occurrence of these species of bacteria including E. coli, Staphylococcus aureus, and Salmonella are recognized to be major causative agent of disease existing in humans by feeding and handling (Pal and Dasgupta, 1992).

A previously done study in Zaire by (Vandamme and Vandepitte, 1980) recommended that the tropical diarrhea in human's sporadic cases could be credited to infections by Edwaedsiella tarda and Pleisomonas shigelloides. The infections could be found to have originated from the consumption or handling of freshwater contaminated fish. Moreover, there are adjacent association among ecological factors and bacteria present in fish ponds including deferred matter, organic debris, planktons, dissolved oxygen, and nutrient salts, and transparency which shows what's more negative or positive relationship (Guo et al., 1988). It is therefore understandable that an administration of pond has a very robust impact on bacterial numbers in the ecosystem of pond. Keeping in opinion of above evidences, it makes available the reference point evidence on the occurrence of bacterial species in species of fish and ponds. Citrobacter freundii, E. coli, Aeromonas hydrophila, Klebsiella species, Enterobacter aerogenes, Vibrio anguillarum, and Pseudomonas species are the common species found in the digestive tract of fish belonged to 7 Gram negative bacterial species, and 3 species of Gram-positive bacteria, including Listeria, Staphylococcus, and Bacillus species. The occurrence of the previous group of bacteria which are associates of the family of Enterobacteriaceae and Vibrio. Aeromonas is a causative apprehension as these organisms are probable enteropathogenesis. Food quality and shelf life are important perceptions for consumers and producers of foods and, it is utmost significant when handling fresh fish where the shelf life can diverge from few days to few weeks at the most.

Moreover, fish is one of the greatest vulnerable foods for damage where sensual characteristics weaken comparatively fast. Fundamental contributing causes for the spoilage is a definite bacterial growth which is administered by the seasons, species of fish, processing, and circumstances of storage. By the processing and handling as well as the temperature and the time that goes between packaging and catching the shelf life and excellence of the fish products is largely exaggerated. The epidermis mucosa natural flora of afresh caught North Atlantic cod from the Icelandic, Baltic, and North Sea has been categorized employing the 16S rRNA clone examination, exposing the Pseudomonas, Photobacterium, Flavobacterium, Psychrobacter and Pseudoalteromonas are the commonly found species on cod epidermis. It was described that Psychrobacter species was the most copious species of a 16S rRNA (Hovda et al., 2007) clone library shadowed by Photobacterium species (Rudi et al., 2004). Where the ecological moralities of succession are as effective as in any other ecosystem upon slaughtering and catching the fish converts to microbial ecosystem of its own. This environment consists of a high content of nutrients with oxygen strain auspicious to the propagation of stronggrowing heterotrophs also accountable for the fish food spoilage. After catch the corrosion of freshness of fish starts rapidly by autolytic action of endogenous enzymes and trailed by lipid oxidation and microbiological 
breakdown of tissues to fish spoilage. Strains of Shewanella putrefaciens and in muscles of fish Pseudomonas species were initial predictable as supposed spoilage inducers and have since then been institute in numerous species of fish from marine and fresh waters in addition to other foods. Classification of Pseudomonas species which were isolated in spoilage of gilt-head sea bream in Greece exposed that $P$. lundensis was the major species nevertheless $P$. fragi, $P$. putida, and $P$. fluorescens were also found. Said species are likely to be among the key fish spoilage organisms in the genus of microorganisms. S. putrefaciens and Pseudomonas species are commonly connected with spoilage of fish kept under the aerobic conditions. In the scenario of packed fish, Photobacterium phosporeum has been described as the chief spoilage microorganism in altered air (Ast and Dunlap, 2005). Pseudomonas species is commonly employed as indicator for bacterial spoilage and is existing in numerous types of food including meat, chicken and fish. Moreover, P. phosporeum can also assist as spoilage indicator but not much considered as like Pseudomonas species. As it provides precise and rapid detection/identification and quantification of such microorganisms in amalgamation with the suitable model system (Martin et al., 1978).

In majority of the natural environments, microorganisms attach to the surface, multiply and form biofilms which make available augmented resistance to external disturbances. At this point associated cells to biofilm are five times more resistant to numerous toxic substances such as chlorine, detergents, and antibiotics (Simoes et al., 2009). The biofilm establishment is generally portrayed as sequence of distinct phases in life cycle which activates when planktonic cells associates surface whether by chemical attractants or arbitrarily. Later on, it includes the irretrievable attachment when cells have bourgeoned and have started to secrete extracellular polymeric constituents including DNA, proteins and polylactides. Microorganisms existing in biofilms are supposed to connect by signaling of chemicals even though orchestrated actions of the community is a matter of argument (Watnick and Kolter, 2002). A modification in expression of genes when cells drive from planktonic state to biofilms is undisputable and is the fundamental reason of different cell actions that symbolizes biofilms. Even though no single mechanism is accountable, numerous species use minimum number sensing to moderate surface attachment, motility, extracellular polymeric production and dispersal. Secreted polymers are significant feature of biofilms but the purposes of them are not yet completely clear (Nadell et al., 2009).

Moreover, biofilms are not limited to normal surroundings as processing of food services are perfect environment for formation of biofilms where nutrient rich liquid occasionally or continually covers the surfaces (Dunne, 2002). This can source problematic to the making if appropriate hygienic precautionary actions are not completed. Unwanted bacteria such as spoilers Pseudomonas species and pathogens Listeria monocytogenes have been exposed to form biofilms in plants of food handling and if the biofilm raises to developed state the danger of determined impurity of these bacteria in the food is ostensible (Xavier and Foster, 2007).

\section{Conclusion}

Consumption of fish and its products are in high demand because of health benefits. Seafood including fish contains valuable amount of lipids, proteins and micronutrients. They have low caloric density and are rich source of omega 3. Protein from different types of fish like salmon, cod, mackerel and herring have antiinflammatory characteristics however in addition to this protein of cod and salmon, also show improved insulin 
sensitivity in rats. Fish is the most delicate aquatic product due to microbial and biochemical post-harvest decomposition. In countries like sub Saharan Africa many species of fish are considered unfit for intake. This is because of hot climate (above 30), lack of facilities for freezing and refrigeration and lack of modern preservation methods. The spoilage results in enzymatic changes which are responsible for variations in flavor, texture and odor of meat. Most prevalent pathogens that are associated to aquatic environments, linked with human foodborne diseases are Yersinia spp., Vibrio spp., Salmonella serovars, Clostridium botulinum and Listeria monocytogenes. Other food borne pathogens responsible for mild to severe infections are Enterococcus, Staphylococcus, Streptococcus, Escherichia coli and Bacillus spp.

\section{Acknowledgements}

The author acknowledges the director of the CASVAB, University of Balochistan, Quetta, who allowed for the research work.

\section{References}

Allen, D. A.; Austin, B. and Colwell, R. R. 1983. Numerical taxonomy of bacterial isolates associated with a freshwater fishery. Journal of General and Applied Microbiology, 129:2043-2062.

Ast, J. C. and Dunlap, P. V. 2005. Phylogenetic resolution and habitat specificity of members of the Photobacterium phosphoreum species group. Environmental Microbiology, 7:1641-1654.

Balasubramanian, S.; Rajan, M.R. and Raj, S.P. 1992. Microbiology of fish grown in a sewage-fed pond. Bioresources Technology, 40:63-66.

Bishor, V. I. and Elezebeth, K. 1989. Sea food toxin. Indian Journal of Food Science and Technology, 28:318321.

Bott, T. L.; Deffner, J. S.; McCoy, E. and Foster, E. M. 1966. Clostridium botulinum in fish from the Great Lakes. Journal of Bacteriology, 91:919-924.

Bottone, E. J.; Bercovier, H. and Mollaret, H. H. 2005. Genus XLI. Yersinia. In: Garrity, G. M., Brenner D. J., Krieg, N. R., Staley, J. T. (eds) Bergey's manual of systematic bacteriology. The proteobacteria. Part B. The gamma proteobacteria, $2^{\text {nd }}$ edn. Springer Press, New York, pp:838-848.

Bresolin, G.; Neuhaus, K.; Scherer, S. and Fuchs, T. M. 2006. Transcriptional analysis of long-term adaptation of Yersinia enterocolitica to low temperature growth. Journal of Bacteriology, 188:2945-2958.

Broza, Y. Y.; Danin-Poleg, Y.; Lerner, L.; Valinsky, L.; Broza, M.; Kashi, Y. 2009. Epidemiologic study of Vibrio vulnificus infections by using variable number tandem repeats. Emerging Infectious Diseases, 15:1282-1285. 
Budzińska, K.; Wroński, G. and Szejniuk, B. 2012. Survival time of bacteria Listeria monocytogenes in water environment and sewage. Pols Journal of Environmental Study, 1:31-37.

Buras, N.; Duek, L.; Niv, S; Hepher, B. and Sandbank, E. 1987. Microbiological aspects of fish grown in treated waste water. Journal of Water Resources, 21:1-10.

Callol, A.; Pajuelo, D.; Ebbesson, L.; Teles, M.; MacKenzie, S. and Amaro, C. 2015. Early steps in the European eel (Anguilla anguilla)-Vibrio vulnificus interaction in the gills: role of the RtxA13 toxin. Fish Shellfish Immunology, 43:502-509.

Christensen, P. J. 1997. The history, biology, and taxonomy of the Cytophaga group. Canadian Journal of Microbiology, 23:1599-1653.

Den-Bakker, H. C.; Warchocki, S.; Wright, E. M.; Allred, A. F.; Ahlstrom, C.; Manuel, C. S.; Stasiewicz, M. J.; Burrell, A.; Roof, S.; Strawn, L.; Fortes E. D.; Nightingale, K. K.; Kephart, K. and Wiedmann, E. 2014. Five new species of Listeria ( $L$. floridensis sp. nov, L. aquatica sp. nov., L. cornellensis sp. nov. $L$. riparia sp. nov., and L. grandensis sp. nov.) from agricultural and natural environments in the United States. International Journal of Systematic Evolution Microbiology, doi:10.1099/ijs.0.052720.

Diler, O. and Diler, A. 1998. Quantitative and qualitative changes of the gastrointestinal microflora of pike-perch (Stizostedion lucioperca L. 1998) in Egirdir Lake. Turkey Journal of Veterinary Animal Sciences, 22:325-328.

Diler, O.; Altun, S.; Calikusu, F. and Diler, A. 2000. A study on qualitative and quantitative bacterial flora of the rainbow trout (Oncorhynchus mykiss) living in different fish farms. Turkey Journal of Veterinary Animal Sciences, 24:251-259.

Dunne, W. M. 2002. Bacterial adhesion: seen any good biofilms lately? Clinical Microbiology Review, 15: 155-166.

Embarek, P. K. P. 1994. Presence, detection and growth of Listeria monocytogenes in seafoods: a review. International Journal of Food Microbiology, 23:17-34.

Ertas, H. B. and Seker, E. 2005. Isolation of Listeria monocytogenes from fish intestines and RAPD analysis. Turkey Journal of Veterinary Animal Sciences, 29:1007-1011.

Evelyn, T. P. T. and McDermott, L. A. 1967. Bacteriological studies of freshwater fish- Isolation of aerobic bacteria from several species of Ontario fish. Canadian Journal of Microbiology, 7:357-382.

Ewing, W. H.; Ross, A. J.; Brenner, D. J. and Fanning, G. R. 1978. Yersinia ruckeri sp. nov., the redmouth (RM) bacterium. International Journal of Systematic Bacteriology, 28:37-44. 
Fach, P.; Perelle, S.; Dilasser, F.; Grout, J.; Dargaignaratz, C.; Botella, L.; Gourreau, J. M.; Carlin, F.; Popoff, M. R.; Broussolle, V. 2002. Detection by PCR-enzyme-linked immunosorbent assay of Clostridium botulinum in fish and environmental samples from a coastal area in Northern France. Applied Environmental Microbiology, 68: 5870-5876.

Gauthier, D.T. 2015. Bacterial zoonoses of fishes: a review and appraisal of evidence for linkages between fish and human infections. Veterinary Journal, 20:27-35.

Geldreich, E.E. and Clarke, N.A. 1996. Bacterial pollution indicators in the intestinal tract of freshwater fish. Applied Microbiology, 14:429-37.

Givens, C. E.; Bowers, J. C.; DePaola, A.; Hollibaugh, J. T. and Jones, J. L. 2014. Occurrence and distribution of Vibrio vulnificus and Vibrio parahaemolyticus - potential role for fish, oyster, sediment and water. Lett Applied Microbiology, 58:503-510.

Guo, X.; Fan, Y.; Wang, J. and Fan, X. 1988. Initial studies on the effects of aquatic bacteria on the ecosystem and fish yield of the manure-loaded ponds. Journal of Academic Fish Sciences, 1:18-28.

Guzman, M. C., Bistoni, M. A. Tamagninii, L. M. and Gonzales, R. D. 2004. Recovery of Escherichia coli in fresh water fish, Jenynsia multidentata and Bryconamericus iheringi. Water Resources, 38:2368-2374.

Hansen, C. H.; Vogel, B. F. and Gram, L. 2006. Prevalence and survival of Listeria monocytogenes in Danish aquatic and fish processing environments. Journal of Food Protection, 69:2113-2122.

Hovda, M.B.; Lunestad, B.T.; Sivertsvik, M. and Rosnes, J. T. 2007. Characterization of the bacterial flora of modified atmosphere packaged farmed Atlantic cod (Gadus morhua) by PCR-DGGE of conserved 16S rRNA gene regions. International Journal of Food Microbiology, 117:68-75.

Huss, H.H. and Pedersen, A. 1979. Clostridium botulinum in fish. Nordisk Veterinary Medicine, 31:214-221.

Johannsen, A. 1962. Clostridium botulinum in Sweden and the adjacent waters. Journal of Applied Bacteriology, 26:43-47.

Karapinar, M. and Gonul, S.A. 1991. Survival of Yersinia enterocolitica and Escherichia coli in spring water. International Journal of Food Microbiology, 13:315-319.

Leclair, D.; Farber, J. M.; Doidge, B.; Blanchfield, B.; Suppa, S.; Pagotto, F. and Austin, J. W. 2012. Distribution of Clostridium botulinum type E strains in Nunavik, Northern Quebec, Canada. Applied Environmental Microbiology, 79:646-654.

Lianou, A. and Sofos, J. N. 2007. A review of the incidence and transmission of Listeria monocytogenes in readyto-eat products in retail and food service environments. Journal of Food Protection, 70:2172-98. 
Lindström, M.; Vuorela, M.; Hinderink, K.; Korkeala, H.; Dahlsten; Raahenmaa, M. and Kuusi, M. 2006. Botulism associated with vacuum-packed smoked whitefish in Finland. Euro Surveillance, 11(29):3004.

Martin, R. E.; Gray, R. J. H. and Pierson, M. D. 1978. Quality assessment of fresh fish and the role of the naturally occurring microflora. Food Technology, 5:188-192.

Merivirta, O. L.; Lindström, M.; Björkroth, K. J. and Korkeala, H. 2006. The prevalence of Clostridium botulinum in European river lamprey (Lampetra fluviatilis) in Finland. International Journal of Food Microbiology, 109:234-237.

Nadell, C. D.; Xavier, J. B. and Foster, K. R. 2009. Microbial biofilms: from ecology to molecular genetics. Microbiology Molecular Biology Review, 64:847-867.

Nakaguchi, Y. 2013. Contamination by Vibrio parahaemolyticus and its virulent strains in seafood marketed in Thailand, Vietnam, Malaysia, and Indonesia. Tropical Medical Health, 41:95-102.

Nedoluha, P. C. and Westhoff, D. 1997. Microbiological analysis of striped bass (Morone saxatilis) grown in a recirculating system. Journal of Food Protection 60:948-953.

Noorlis, A.; Ghazali, F. M.; Cheah, Y. K.; Zainazor, T. C.; Ponniah, J.; Tunung, R.; Ting, J. Y. H.; Nishibuchi, M.; Nakaguchi. Y. and Son, R. 2011. Prevalence and quantification of Vibrio species and Vibrio parahaemolyticus in freshwater fish at hypermarket level. International Food Research Journal, 18:689695.

Pal, D. and Dasgupta, C. D. 1992. Microbial pollution in water and its effect on fish. Journal of Aqua, Animal Health 4:32-39.

Pillay, T. V. R. 1990. Fish and public health and disease. In: Pillay TVR Aquaculture principles and practices. Fishing News Book. Farnham, UK, 23:174-215.

Reichenbach, H. H. 1973. Fish Pathology. Neptune City, N. J., T. F. H. Publications, 286.

Rocke, T. E.; Nol, P.; Pelizza, C.; Sturm, K. 2004. Type C botulism in pelicans and other fish-eating birds at the Salton Sea. Study Avian Biology, 27:137-140.

Rudi, K.; Maugesten, T.; Hannevik, S.E. and Nissen, H. 2004. Explorative multivariate analyses of 16S rRNA gene data from microbial communities in modified-atmosphere-packed salmon and coalfish. Applied Environmental Microbiology, 70:5010-5018.

Senderovich, Y.; Izhaki, I. and Halpern, M. 2010. Fish as reservoirs and vectors of Vibrio cholerae. PLoS One, 5:604-607. 
Simoes, M.; Simoes, L. C. and Vieira, M. J. 2009. Species association increases biofilm resistance to chemical and mechanical treatments. Water Resources, 43:229-237.

Smith, L. D. S. and Sugiyama, H. 1998. Botulism: the organism, its toxins, the disease, $2^{\text {nd }}$ edn. Springfield, Illinois, pp:139-145.

Sulakvelidze, A. 2002. Yersiniae other than Y. enterocolitica, Y. pseudotuberculosis, and Y. pestis: the ignored species. Microbes Infection, 2:497-513.

Tao, Z.; Larsen, M. A.; Bullard, S. A.; Wright, A. C. and Arias, C. R. 2012. Prevalence and population of Vibrio vulnificus on fishes from the Northern Gulf of Mexico. Applied Environmental Microbiology, 78:76117618.

Toranzo, A. E.; Novoa, B.; Romalde, J. L.; Nunez, S.; Devesa, S.; Marino, E.; Silva, R.; Martizen, E.; Figueras, A. and Barja, J. L. 1993. Microflora associated with healthy and diseased turbot (Scophthalmus maximus) from 3 farms in Northwest Spain. Aquaculture, 114:189-202.

Trust, T. J. and Sparrow, R. A. H. 1994. The bacterial flora in the alimentary tract of freshwater salmonid fish. Canadian Journal of Microbiology, 20:1219-1228.

Tsubokura, M. and Aleksić, S. A. 1995. Simplified antigenic scheme for serotyping of Yersinia pseudotuberculosis: phenotypic characterization of reference strains and preparation of $\mathrm{O}$ and $\mathrm{H}$ factor sera. Contribution Microbiology Immunology, 13:99-105.

Vandamme, L. R. and Vandepitte, J. 1980. Frequent isolation of Edwardsiella tarda and Pleisomonas shigelloides from healthy Zairese freshwater fish: A possible source of sporadic diarrhoea in the tropics. Applied Environmental Microbiology, 50:930-933.

Wagner, M. and McLauchlin, J. 2008. Biology. In: Liu D (ed) Handbook of Listeria monocytogenes. CRC Press, Washington, pp:3-27.

Watnick, P. and Kolter, R. 2002. Biofilm, city of microbes. Journal of Bacteriology, 182:2675-2679.

Wauters, G.; Kandolo, K. and Janssens, M. 1987. Revised biogrouping scheme of Yersinia enterocolitica. Contribution Microbiology Immunology, 9:14-21.

Weber, J. T.; Hibbs, R. G.; Darwish, A.; Mishu, B.; Corwin, A. L.; Rakha, M.; Hatheway, C. L.; El-Sharkawy, S.; El-Rahim, S. A.; Al-Hamd, M. F.; Sarn, E. J.; Blake, P. A. and Tauxe, R.V. 1993. A massive outbreak of type E botulism associated with traditional salted fish in Cairo. Journal of Infectious Disease 167:451454. 
The Journal of Microbiology and Molecular Genetics (JMMG)

Vol. 2, No. 4 (2021), Article No. 1, pp. 1-13

Xavier, J. B. and Foster, K. R. 2007. Cooperation and conflict in microbial biofilms. Proceedings of National Academy of Sciences, 104:876-881.

Youssef, H.; El-Timawy, A. K. and Ahmed, S. 1992. Role of aerobic intestinal pathogens of fresh water fish in transmission of human diseases. Food Control, 4:34-40. 